\title{
Nasilje u hrvatskim dječjim serijama Jelenko i Smogovci
}

Prethodno priopćenje__DOI 10.22522/cmr20190147_ primljeno 20. siječnja 2018.

UDK: $654.172: 791.43 .05(05)$

$177.8: 791.43 .05(05)-053.5(497.5)$

\section{Lina Malek}

Hrvatski studiji (doktorandica), Zagreb, Hrvatska.

E-adresa: lina.malek@gmail.com

\section{Tina Regg}

Društvo za komunikacijsku i medijsku kulturu, Zagreb, Hrvatska.

E-adresa: tina.hrubi@gmail.com

\section{Katarina Blažina Mukavec}

Društvo za komunikacijsku i medijsku kulturu, Zagreb, Hrvatska.

E-adresa: blazina0307@gmail.com

\section{Sažetak}

Nasilje u medijima posljednjih je godina tema sve većeg broja znanstveno-istraživačkih radova koji ukazuju na povezanost nasilja na ekranima s nasiljem u stvarnome životu. Televizija je i dalje popularan medij kod djece, a količina nasilnih sadržaja na televiziji konstantno raste sukladno razvoju tehnologije i potraživanjima publike. Cilj je ovog rada ukazati na prisutnost nasilja u poznatim hrvatskim dječjim serijama Jelenko i Smogovci. lako je riječ o popularnim serijama za djecu, gotovo svaka analizirana epizoda sadrži neki oblik nasilja, a fizičko nasilje je najzastupljenije. Unatoč tomu što svakodnevno raste broj radova o nasilju u medijima, i dalje nedostaje radova u kojima se govori o nasilju u hrvatskim dječjim serijama, pa je jedno od nastojanja ovog rada potaknuti daljnja istraživanja u ovom području.

KIjučne riječi: televizija, nasilje, hrvatske dječje serije, Smogovci, Jelenko 


\section{Uvod}

Mediji imaju utjecaj na odrastanje i odgoj djece, tvrdi Nada Zgrabljić Rotar (2005, str. 7-8), premda ne postoji univerzalan stav o tome je li taj utjecaj pozitivan ili negativan. Mladima je, prema Vlasti Ilišin (2003, str. 29), osim druženja s prijateljima (vršnjacima), korištenje medija (računala i televizije) najčešća aktivnost u slobodnom vremenu. Postotak gledanja televizije je u 1999. godini iznosio 70,9 \%, u 2004. 80,9 \%, a u 2013. godini bilježi se pad gledanja televizije pa tek 53,2 \% mladih kaže da odabiru televiziju kao aktivnost tijekom slobodnog vremena (Ilišin, 2017, str. 300). Očito je da računalna tehnologija zauzima važnije mjesto među mladima, ali i dalje mnogi gledaju i televiziju. Mediji imaju veliki utjecaj na djecu - oni uče promatrajući, imitirajući i usvajajući ponašanja (Bandura, 1994). Djeca u dobi od 8 do 18 godina u prosjeku provedu više od 6 sati dnevno uz zabavne medijske sadržaje, a u njih svakako spada i televizija (Američka pedijatrijska akademija, 2009). Prema istraživanju Ofcoma (2017) mlađa djeca, ona u dobi od 3 do 4 godine, i dalje najviše medijskih sadržaja prate na televiziji ( $88 \%$ ), dok se kod starije djece, od 12 do 15 godina, taj postotak smanjuje (62 \%), ali i dalje televizija ostaje najpraćeniji medij. Poliklinika za zaštitu djece i mladih Grada Zagreba u suradnji s Hrabrim telefonom (2017) provela je prvo nacionalno istraživanje o predškolskoj djeci pred malim ekranima te rezultati pokazuju kako djeca te dobi i dalje najviše vremena provode pred televizorima (97,2 \% vikendom i 95,5 \% radnim danom). Igor Kanižaj i Lana Ciboci (2011, str. 12) smatraju da mediji, „prije svega televizija, ... postaju odgojitelji mlađih generacija“ te da njihovi roditelji, zbog prevladavajućeg načina života, često nemaju svijest o negativnim utjecajima koje mediji mogu imati na djecu. Neupitno je da se količina nasilja u medijskim, ponajviše televizijskim sadržajima, sve više povećava. Budući da u školama još uvijek ne postoji zaseban predmet medijske kulture gdje bi se sustavno moglo učiti o nasilju u medijima, može se pretpostaviti da neka djeca i dalje nisu svjesna utjecaja medijskog nasilja na njih same.

Cilj je rada, koristeći kvantitativnu analizu sadržaja, ukazati na prisutnost nasilja u poznatim hrvatskim dječjim serijama Jelenko i Smogovci s obzirom na to da u Hrvatskoj nedostaje radova o dječjim serijama i nasilju u njima. Nastojale smo potvrditi nasilne scene u sadržaju za djecu i time pridonijeti činjenici da i sadržaj namijenjen djeci obiluje nasiljem, a ne samo sadržaj za odrasle. U radu se govori s medijskog polazišta u kojem se smatra da nasilni televizijski sadržaj može stvoriti negativne posljedice, ali će se spomenuti i one teorije koje pokazuju da prikaz nasilnog ponašanja u medijima može imati i pozitivne posljedice. 
Smogovcima se bavio samo Igor Duda (2014), a serija Jelenko u potpunosti je neistražena. Među domaćim stručnjacima koji su se bavili televizijskim nasiljem treba izdvojiti Zlatka Miliša i Jasminku Zloković (2008), Jadranku Žderić (2009), Jerka Valkovića (2010), Igora Kanižaja i Lanu Ciboci (2011), Valentinu Mandarić (2012), a televizijske serije i nasilje u posljednje vrijeme sve češće postaju tema završnih i diplomskih radova ${ }^{1}$. Ukratko je te dvije serije u svojem diplomskom radu opisala Patricia Miljak (2015), no nije se dotakla nasilja u njima. Autorice ovoga rada s komunikološkog aspekta nastoje saznati u kojoj od tih dviju serija ima više medijskog nasilja, kakvo je ono (fizičko, verbalno i/ili psihičko) i koliko su učestale nasilne scene budući da hrvatska znanost oskudijeva u istraživanju nasilnih scena domaćih dječjih serija. Autorice se pritom vode činjenicom na koju su upozorili Bruce D. Bartholow i suradnici još 2006. godine, a prema kojoj izloženost medijskom nasilju povećava agresiju kod medijskih korisnika (prema Kanižaj, Ciboci, 2011, str. 19).

\section{Televizija i nasille}

Već na početku devedesetih godina prošlog stoljeća, Huston i suradnici zaključili su da će djeca do završetka svog osnovnoškolskog obrazovanja vidjeti osam tisuća ubojstava i sto tisuća drugih oblika medijskog nasilja, dok će u stvarnom životu vidjeti manje od jedan posto nasilnih djela (prema Kirsh, 2006, str. 202). Preko medija će, procjenjuje se (Trend, 2007, str. 4), jedna mlada osoba do svoje osamnaeste godine vidjeti dvjesto tisuća simuliranih nasilnih djela i više od šesnaest tisuća dramatiziranih ubojstava. Kanižaj i Ciboci (2011, str. 12) napominju kako djeca više vremena provode pred ekranima, nego što ga provode u školi ili u druženju s vršnjacima u prirodi.

\subsection{Televizijske navike djece}

Donald F. Roberts, Ulla G. Foehr, Victoria J. Rideout i Maryanne Brodi smatraju da djeca preferiraju dječji i obrazovni program te humoristične serije (prema Ilišin, 2001, str. 22). Manca Košir, Nada Zgrabljić i Rajko Ranfl istraživanjem su pak utvrdili da djeca rado odabiru akcijske i horor filmove te razne serije (prema Ilišin, 2001, str. 22). Televizija je zanimljiva i privlačna djeci jer ima različita svojstva: „posredovanje slike i zvuka, veliki izbor programa, raznovrsnost sadržaja, manja zahtjevnost pri upotrebi, laka dostupnost“

1 Benko, 2015; Fabijanić, 2015; Lucić, 2016; Miljak, 2015; Mitorvić, 2015. 
(Ilišin, 2001, str. 22). Prema rezultatima istraživanja, 77 \% djece redovito prati igrane filmove i serije (Ilišin, 2001, str. 150).

Krešimir Mikić (2001) ističe tri razloga kod djece za gledanje televizije: humor, neustrašivi junaci i akcija. Ti razlozi također govore o tome što djeca očekuju od televizije, a to je zabava, relaksacija, humorističnost, napetost, zanimljivost, mogućnost poistovjećivanja s junacima, otkrivanje novih svjetova, što sve dovodi do zadovoljenja njihove znatiželje (Mikić, 2001 prema Mlinarević, 2004, str. 42). Od televizijskih žanrova prednost daju crtanim serijama i filmovima. Mikić (2001, str. 251) tvrdi da „dječaci u crtanim filmovima preferiraju akcijske prizore, a djevojčice to smatraju 'dječjim serijama'. One više vole filmove koji obiluju emocijama i melodramatičnošću. Pritom ne zanemaruju humor, tempo i napetost, ali ne vole gledati grube borbe i filmove koji obiluju trikovima“" (prema Mlinarević, 2004, str. 42). Istraživanje Vesnice Mlinarević, provedeno u slavonskim dječjim vrtićima, pokazalo je da djeca preferiraju crtane filmove, emisiju Dobro jutro Hrvatska, seriju Smogovci te Story Super Nova (2004, str. 42).

\subsection{Televizijsko nasilje}

Nasilje je vrlo teško jednoznačno i potpuno definirati. No, Kanižaj i Ciboci pišu da će veći broj nasilnih sadržaja biti zabilježen ako i definicija bude šira (2011, str. 15). Ono što uvjetuje širinu jesu elementi na koje se misli pri definiranju nasilja. Ti su elementi, smatra William James Potter (1999, str. 64), namjera (jesu li nasilje samo fizička djela s namjerom ili i prirodne katastrofe?), šteta (nasilje je bol uzrokovana samo ljudima ili i životinjama i ona počinjena nad materijalnim stvarima?) te vrsta nasilja (govori li se samo o fizičkom ili i o verbalnom nasilju?) (prema Kanižaj, Ciboci, 2011, str. 15). Jedno od prvih psiholoških istraživanja definiralo je nasilje kao „ponašanje koje je usmjereno ozljeđivanju drugog bića pri čemu je ključna bila namjera za ozljeđivanje drugih“ (prema Kanižaj, Ciboci, 2011, str. 15). Autori napominju da je Albert Bandura pod nasiljem smatrao i ozljeđivanje drugih živih bića i uništavanje imovine (Kanižaj, Ciboci, 2011, str. 15). Barrie Gunter i suradnici (prema Kanižaj, Ciboci, 2011, str. 15) ustanovili su da je George Gerbner u nasilna djela ubrojio nesreće, katastrofe i prirodne nepogode, ali je isključio prazne prijetnje, verbalno nasilje i humoristične geste bez vjerodostojnih nasilnih posljedica. Autor jedne od definicija je i Potter (1999, str. 69) koji tvrdi da je nasilje „povreda nečije fizičke i emocionalne dobrobiti“ i i obuhvaća sve dosad navedene elemente (prema Kanižaj, Ciboci, 2011, str. 16). 
Valković (2010, str. 67) smatra da se nasilje na televiziji ne može jednoznačno prikazati, već ga je potrebno predočiti kroz funkcije i značajke televizijskih programa. Kada govori o karakteristikama televizijskog djelovanja, Valković (2010, str. 69) napominje da je televizija medij koji sadržaj predočuje slikom te pritom potiče emocije koje su vrlo intenzivan način komuniciranja. Televizija se obraća različitoj publici, a pritom je ono što prikazuje „mješavina“ virtualnog i realnog (Valković, 2010, str. 70). Osim u filmovima, nasilje je prisutno i u serijama. Iako Buonanno piše o karakteristikama nasilja u policijskim serijama, one se mogu primijeniti i na dječje humoristične serije analizirane $u$ našem istraživanju. Tako Buonanno (prema Valković, 2010, str. 74) ističe sljedeće elemente: svojevrsna lakoća radnje u kojoj se miješaju dramatično i komično; obiteljski, prijateljski ili susjedski odnosi kao središte radnje te „domaća“ atmosfera.

Televizijsko nasilje Valković predočuje putem temeljnih obilježja. Autor ističe da će nasilje na TV-u biti prikazano u „soft“ obliku jer si televizija ne može dozvoliti odbačenost od publike. Također je često prikazivanje nasilja preko spontanih priča protagonista, $u$ obliku talk-showa. Valković ne zaboravlja ni na monopol koji televizija ima pa piše da TV ponekad može „usmjeravati prema pobuđivanju stavova ili širenju poruka netrpeljivosti prema nekim osobama, grupama, narodima ili pak usmjeravati javnost na ono što ne zaslužuje takvu pozornost“ (2010, str. 77).

Kao i gledatelji, tako i televizijski djelatnici vide nekoliko opravdanih razloga za pojavu nasilja na ekranima. S obzirom na to da je nasilje dio života, onda se može reći da mediji „nasiljem prikazuju stvarnost kakva ona uistinu jest“; nasilje je dobra podloga za izgradnju akcije i primamljiva tema; za adolescente nasilje može biti iskustvo „suočavanja i gledanja smrti licem u lice“ (Valković, 2010, str. 78). Važno je imati na umu da televizija tako postaje sredstvo i izvor za iskušenje raznolikih iskustava (Valković, 2010, str. 79). Autor napominje da postoje i neki manje uočljivi razlozi nasilja na ekranima kao što su zarada, odgojna funkcija takvog sadržaja budući da se njegovim prikazivanjem „sankcioniraju, reorganiziraju socijalne norme koje su u nekom trenutku bile prekršene“ te politički/ ideološki razlozi temeljem kojih se stvaraju nove situacije (2010, str. 79). Valković zaključuje kako prilikom promišljanja o motivima televizijskog nasilja svakako treba imati na umu „širi kontekst funkcioniranja televizije, njezinu ulogu koju ima u društvu, ali i ciljeve koje nastoje provoditi oni koji imaju kontrolu nad televizijom“ (2010, str. 79). Potter (1999) navodi sedam značajki televizijskog nasilja (prema Ciboci, Osmančević, 2014, str. 7): 
1. Većina nasilnih djela na televiziji počinjena su s namjerom - rijetko se prikazuju nesreće kao oblici nasilnih djela.

2. Rijetko se prikazuju posljedice za žrtve nasilnih djela - u većini prikaza nasilnih sadržaja, rijetko se prikazuju bol i patnja žrtvi nasilnih djela.

3. Počinitelji nasilnih djela često prolaze nekažnjeno, prikazani su vrlo atraktivno i snažnih osobnosti.

4. Većina nasilnih djela na televiziji opravdana je iz perspektive počinitelja, ali ne i šireg društva.

5. Uz nasilna djela često se prikazuje oružje. Najčešće korišteno oružje na televiziji je pištolj.

6. Nasilje na televiziji najčešće se prikazuje na humorističan način. Humoristični prikazi nasilnih sadržaja najčešći su u dječjim programima.

Počinitelji i žrtve nasilnih djela najčešće su muškarci srednje životne dobi (između 20 i 50 godina).

\subsection{Teorije o utjecaju televizijskog nasilja}

Jedna od najstarijih teorija (Kanižaj, Ciboci, 2011, str. 17) je teorija o katarzi koja podrazumijeva da gledanje medijskog nasilja kod gledatelja inspirira maštanje u kojem gledatelj sebe zamišlja u takvoj situaciji. No, nema dovoljno jakih empirijskih dokaza koji bi poduprli ovu teoriju (Kanižaj, Ciboci, 2011, str. 17). Prema teoriji o navikavanju, „smanjuje se sposobnost empatije, (...) a nasilje se počinje doživljavati normalnim (...) načinom rješavanja konflikata“ (Kunczik, Zipfel, 1998, str. 224 prema Kanižaj, Ciboci, 2011, str. 17). Kultivacijskom teorijom, koju je stvorio Gerbner 1969. godine, bilježi se da osobe koje više gledaju nasilje na televiziji ujedno doživljavaju svijet opasnijim mjestom (Kanižaj, Ciboci, 2011, str. 18). Također je moguće da se strah ne pojavljuje zbog intenzivne konzumacije televizijskih sadržaja, nego da plašljivi ljudi ostaju kod kuće i gledaju televiziju kako bi izbjegli dodir s „opasnim svijetom“ (Kunczik, Zipfel, 2007, str. 6 prema Kanižaj, Ciboci, 2011, str. 18). Bandura je teorijom o socijalnom učenju predočio da se „agresivno ponašanje može naučiti kroz promatranje tuđega agresivnog ponašanja“ (Kanižaj, Ciboci, 2011, str. 18), pri čemu model za imitaciju ne mora nužno biti živa osoba, 
nego i lik iz filma. Kanižaj i Ciboci (2011, str. 18), pozivajući se na Zillmanovu teoriju o prijenosu stanja uzbuđenosti, ukazuju na to da se kod osoba koje su gledale medijsko nasilje, i time povećale svoj stupanj uzbuđenja, može uočiti veći stupanj agresivnog ponašanja u odnosu na one osobe koje su gledale nenasilne ili neutralne filmove.

Priming teorija polazi od podražaja koji kod medijskih potrošača pobuđuju neku reakciju i potiču određena ponašanja (Kanižaj, Ciboci, 2011, str. 19). Ovu je teoriju objasnio Leonard Berkowitz koji je rekao kako su za nasilno ponašanje bitni unutarnji (frustracija, ljutnja) i vanjski čimbenici (koji izazivaju agresiju, a povezani su s ljutnjom i nasiljem) (Kanižaj, Ciboci, 2011, str. 19). „Skripti sadržavaju podatke o tipičnom ponašanju i na taj način usmjeravaju ljudsko ponašanje“ (Kanižaj, Ciboci, 2011, str. 19), što znači da ljudi uče obrasce ponašanja iz medija u kojima se sukobi najčešće rješavaju putem nasilja. Valković (2010, str. 81-82) spominje još Wertherov učinak koji se odnosi na medijsko/televizijsko predstavljanje koje može poticati na suicidalno ponašanje, pri čemu se taj učinak povezuje sa zamišljenim ili stvarnim događajem o kojem govore mediji. U 2007. postalo je jasno da teza o nedjelotvornosti medijskog nasilja nije više održiva i jedva da je itko više zastupa, naglašavaju Michael Kunczik i Astrid Zipfel (2007, str. 20).

Potter je 1999. godine utjecaje medijskog nasilja podijelio na fiziološke, emocionalne, kognitivne i promjene u stavovima i ponašanju te ih svrstao u kratkoročne i dugoročne od ubrzanih otkucaja srca i ritma disanja, znojenja i povišenja krvnog tlaka, preko straha, bijesa i tuge, do učenja novih oblika ponašanja i navikavanja na nasilje ili toleriranja nasilja kao prihvatljivog oblika ponašanja (prema Kanižaj, Ciboci, 2011, str. 19-21).

Kunczik i Zipfel su uočili elemente koji utječu na djelovanje nasilja. To su „karakteristike televizijskog sadržaja, karakteristike osobe koja gleda nasilne programe i karakteristike društvenog okruženja“ (Valković, 2010, str. 83). Dakle, treba razmišljati o mjeri i intenzitetu prikazanog nasilja, o načinu na koji je nasilnik prikazan, tj. je li opravdan njegov čin, zatim je važno misliti o godinama, spolu i društveno-ekonomskom statusu gledatelja i naposljetku o obiteljskom okruženju. Valković naglašava da sve elemente treba uzeti u obzir budući da „govore o složenosti i potrebi slojevitog promatranja utjecaja televizijskog nasilja“ (2010, str. 84). Rezultati istraživanja Vesne Bilić (2010, str. 275) o povezanosti učestalosti gledanja nasilnih sadržaja u televizijskim programima $s$ agresivnim postupanjem prema vršnjacima ukazuju na to da „učenici koji gledaju TV emisije u kojima ima više nasilja, češće iskazuju i sva tri oblika nasilnog ponašanja prema ostalim učenicima“. Time je Bilić (2010, str. 275) potvrdila slične teorije stranih stručnjaka 
(Anderson, Bushman, 2002; Huesmann i sur., 2003; Gentile i sur., 2003, 2004; Huesmann, Taylor, 2006).

Prikazi nasilja ponekad su u funkciji veličanja žrtve nekog heroja ili veličanja pobjede, a ponekad je cilj nasilne scene bio izazivanje emocionalne reakcije (Valković, 2010, str. 68). Takvim herojskim prikazom ukazuje se na „pozitivnu“ sliku nasilja budući da nasilje može postati „sredstvo za učenje, moralno-filozofsko promatranje, kolektivnu participaciju ili čak i prigoda za estetski doživljaj“ (Valković, 2010, str. 69).

Nensi Blažević smatra da „najosjetljivija skupina društva - djeca - gledajući televiziju mogu biti izložena pozitivnim, takozvanim prosocijalnim sadržajima, ali i onima koji mogu biti štetni za njihov razvoj, kao što su nasilje ili 'isprazni sadržaji'“ (2012, str. 480). U svojem istraživanju o ulozi televizije u životima djece vrtićke dobi (Blažević, 2012, str. 492), korištenjem metode fokus grupe na malom broju ispitanika, zaključila je da se kao 'zabranjeni' televizijski sadržaj pojavljuju scene nasilja i one scene verbalnog izražavanja u kojima se koristi neprimjereni rječnik. Blažević napominje da roditelji djeci „objašnjavaju što ponekad ne smiju gledati, ali ne i zašto" (2012, str. 492). S Blažević se slaže i Jasna Šego (2009, str. 66) koja piše kako televizija može pozitivno djelovati na obrazovanje, izražavanje i intelektualni razvoj djece, ali i da televizijski sadržaji mogu imati negativan utjecaj na dječju psihu. Autorica naglašava da djeca razmišljaju konkretno i pritom ne razumiju simbole, usporedbe i metafore, već sve što vide shvaćaju doslovno (2009, str. 67). Šego piše da postoji vjerojatnost „da će se djeca koja svakodnevno gledaju scene nasilja i sama tako ponašati“ (2009, str. 67). O dvojnosti utjecaja televizijskog sadržaja podsjećaju Danijela Blanuša Trošelj i Suzana Srića napominjući da se „adekvatnom, kontroliranom i planiranom upotrebom tv-sadržaja može (...) pozitivno utjecati na motivaciju djece, (...) a da pretjerana i nekontrolirana izloženost može dovesti do pojave niza problema, od gojaznosti, agresivnog ponašanja, straha i sl.“ (2014, str. 25).

Autori Preporuka za zaštitu djece i sigurno korištenje elektroničkih medija (Agencija za elektroničke medije, 2016) napominju da „sama izloženost medijskom nasilju neće pretvoriti dobro funkcionirajuće dijete ili adolescenta normalnog razvoja $u$ nasilnu osobu ili zlostavljača. Za to je potrebna prisutnost drugih čimbenika u životu tog djeteta, kao što su socijalna isključenost, neadekvatno roditeljstvo i drugi situacijski čimbenici. Također, treba naglasiti kako je najvažniji aspekt djelovanja medijskog nasilja na nasilje u stvarnom životu dugoročna kumulacija njegovih učinaka tijekom gledanja većeg broja nasilnog sadržaja tijekom duljeg razdoblja, često više godina.“ 
Huesmann i suradnici, kako pišu Kanižaj i Ciboci (2011, str. 28), proveli su istraživanje koje je pokazalo da „televizijsko nasilje recipirano u djetinjstvu, i kod dječaka i kod djevojčica, u kasnijem životu pogoduje pojavljivanju agresivnog ponašanja. (...) Uzrok tako 'očite’ veze u prvom je redu poistovjećivanje gledatelja s agresivnim protagonistima i njihovo shvaćanje da je televizijski program realističan." Kanižaj i Ciboci (2011, str. 27) su zabilježili da „nasilje prikazano u negativnom svjetlu možda neće stvoriti negativne posljedice (NTVS, 1999 prema Trend, 2007, str. 44), no u svim ostalim okolnostima moramo imati na umu da postoji mogućnost za višestruke negativne posljedice“. Time su Kanižaj i Ciboci nastojali ukazati na to da nasilni medijski sadržaji mogu imati i pozitivnu i negativnu sliku, ovisno o kontekstu izlaganja medijskim sadržajima. Valković zaključuje kako „problemi mogu nastati, osobito za djecu i mlade, budući da ih televizija suočava sa situacijama i temama koje oni zbog svoje dobi i nedovoljnog iskustva još nisu sposobni razumjeti, te takve situacije ostaju neobjašnjene" (2010, str. 84). Upravo se u tome krije velika potreba za kvalitetnim dijalogom između roditelja i djece, kao i njihovih učitelja i odgajatelja, koji su djeci i mladima dužni objasniti svaku situaciju koju nisu razumjeli, koja ih je prestrašila, zabrinula ili na bilo koji drugi način negativno utjecala na njih.

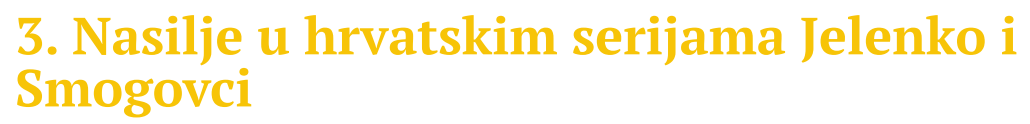

Prva hrvatska dječja serija ${ }^{2}$ Jelenko snimljena je 1980. godine, a sastoji se od 13 epizoda $\mathrm{u}$ trajanju od pola sata. Radnja serije prati skupinu djece koja u svojoj misiji spašavanja planeta od lovokradica doživljava razne avanture i nezgode. Serija „pripada vrhu dječje filmske i TV produkcije“ (Novak, 2006) te ne čudi što je u vrijeme prikazivanja bila iznimno popularna. Osim Leksikona radija i televizije HRT-a, druga literatura o seriji nije pronađena.

Roman Hrvoja Hitreca Smogovci bio je podloga za „najdulju igranu seriju Hrvatske televizije“ (Novak, 2006, str. 402). Sedmorica braće Vragec glavni su likovi popularne serije za djecu i mlade koja je snimana od 1982. do 1997. godine. U četiri ciklusa, odnosno šest sezona, snimljeno je 38 epizoda, a svaka je trajala oko trideset minuta. Televizijske dogodovštine poznate obitelji Vragec iz Naselka sa zagrebačke Pešćenice odvijale su se u

2 Prilikom pretraživanja nije pronađena niti jedna ranije snimljena hrvatska serija za djecu. 
sedamdesetim i osamdesetim godinama 20. stoljeća (Novak, 2006, str. 402-403). Duda je opisao sadržaj serije kao zabavan i ležeran (2014, str. 402), Vinko Paić zaključio je da se radi o „humorističnoj dramskoj seriji“ (2017), no koliko je humora prisutno u epizodama, pokazat će se u nastavku.

\subsection{Metodologija istraživanja}

Kvantitativna analiza sadržaja nasilnih scena u serijama Smogovci i Jelenko provedena je s ciljem određivanja količine nasilja u njima. Smogovci su odabrani jer su se u 2017. prikazivali na Hrvatskoj radioteleviziji, a Lina Malek njima se bavila još 2015. kada je upozorila na odgojnu ulogu Smogovaca i nasilje u crtiću Ptica trkačica koji je bio indirektno prikazan u seriji (Global, 2016). Serija Jelenko odabrana je zato što bilježi visoku gledanost (Novak, 2006).

Jedinica analize je scena, „skupina kadrova povezanih jedinstvom vremena, mjesta i radnje“ (Enciklopedija.com, n.p.). Pod pojmom „nasilna scena“ podrazumijevamo one scene $\mathrm{u}$ kojima se pojavljuje verbalno, fizičko i/ili psihičko nasilje. U svrhu provedbe analize sadržaja sastavljena je analitička matrica koja se sastojala od 24 pitanja, otvorenog i zatvorenog tipa, koja su obuhvatila sljedeće: radi li se u analiziranim scenama o nasilju nad ljudima, životinjama ili materijalnim stvarima; je li nasilje učinjeno s namjerom ili se radi o nesretnom slučaju; prikazuje li scena verbalno, fizičko ili/i psihičko nasilje. Daljnjim pitanjima odredile smo tko su sudionici nasilja; koliki broj osoba sudjeluje u nasilju; je li riječ o prirodnoj katastrofi ili fantaziji; je li nasilje vidljivo te je li prikazano na humorističan način. Posljednjim pitanjima utvrđeno je kojeg je/su spola žrtva/e i počinitelj/i nasilja.

Istraživanje je provedeno na uzorku od 13 epizoda serije Jelenko i 13 epizoda serije Smogovci. Valja napomenuti da serija Jelenko ima sveukupno 13 epizoda, dok serija Smogovci ima šest sezona s 5 ili 6 epizoda. Za uzorak je određena svaka prva i posljednja epizoda svake sezone serije Smogovci, kako bi ukupan broj analiziranih epizoda Smogovaca odgovarao broju analiziranih epizoda Jelenka. Prema ciljevima navedenima u uvodnom dijelu, postavljene su sljedeće hipoteze:

$H_{1}$ : Većina epizoda dječjih serija Jelenko i Smogovci sadrži barem jednu nasilnu scenu.

$H_{2}$ : Najčešće nasilje u dječjim serijama Jelenko i Smogovci je ono među djecom.

$H_{3}$ : U nasilnim scenama u dječjim serijama Jelenko i Smogovci najzastupljenije je fizičko nasilje. 


\subsection{Rezultati istraživanja}

U 26 analiziranih epizoda uočeno je 77 scena nasilja - 25 nasilnih scena u Jelenku i 52 nasilne scene u Smogovcima. S obzirom na konciznost rada u nastavku će biti prikazani samo glavni i najrelevantniji rezultati istraživanja putem prikaza potvrda i negacija hipoteza te kroz raspravu koja se nalazi u zasebnom poglavlju, nakon iznesenih rezultata.

$H_{1}$ : Većina epizoda dječjih serija Jelenko i Smogovci sadrži barem jednu nasilnu scenu.

S obzirom na to da čak 92,3 \% analiziranih epizoda serija Jelenko i Smogovci sadrži barem jednu scenu nasilja, potvrđena je prva hipoteza. Zanimljiva je činjenica da govorimo o popularnim serijama koje su, kao i crtani filmovi, primarno namijenjene djeci i mladima, a iz prikazanih rezultata vidimo da obiluju nasilnim scenama. Istraživanja pokazuju da televizijski sadržaji namijenjeni djeci sadrže najveću količinu nasilja (Američka pedijatrijska akademija, 2009), a djeca mlađa od 8 godina ne mogu razlikovati stvarnost od fikcije (Wright i sur., 1994). Stoga ne čudi podatak da nasilje u medijima može doprinijeti agresivnijem ponašanju djece, pojavi noćnih mora i straha od nasilja te može dovesti i do desenzibilizacije na nasilje (Američka pedijatrijska akademija, 2009).

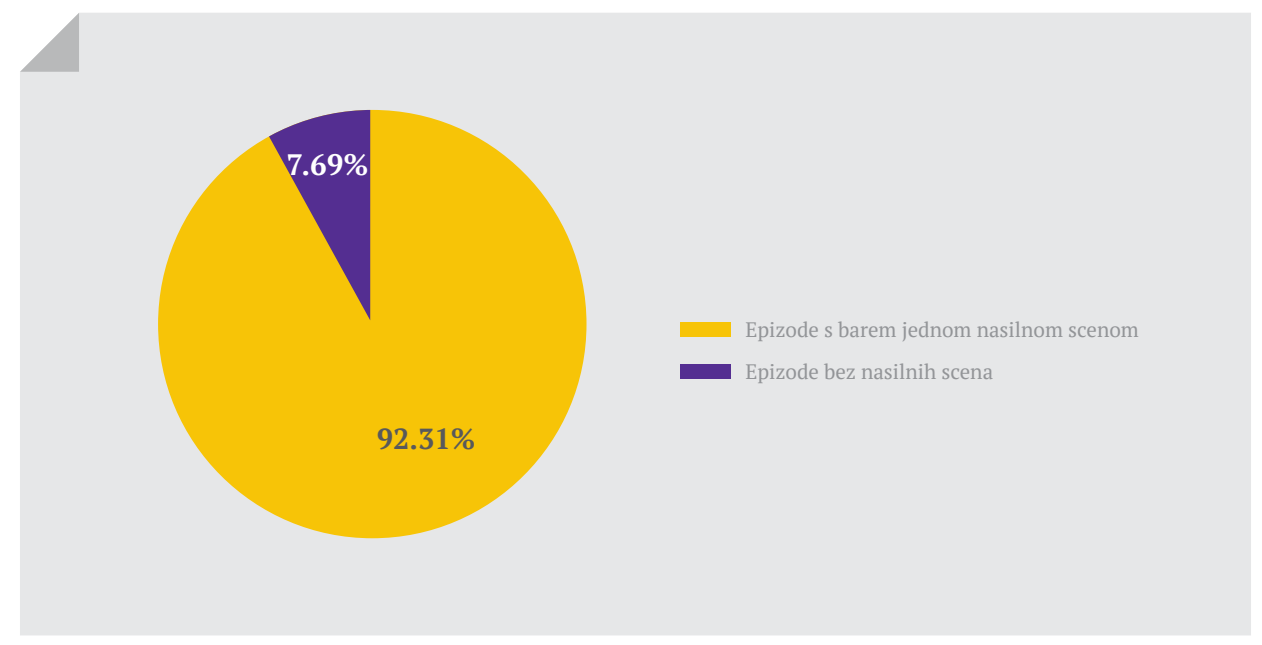

Grafikon 1. Prisutnost nasilja u analiziranim epizodama $(\mathrm{N}=26)$ 
$H_{2}$ : Najčešće nasilje u dječjim serijama Jelenko i Smogovci je ono među djecom.

Budući da govorimo o serijama za djecu, u prvi plan analize stavljeni su oblici nasilja koji uključuju djecu - nasilje odraslih nad djecom, nasilje među djecom i nasilje djece nad odraslima. Poliklinika za zaštitu djece Grada Zagreba je 2003. godine provela istraživanje o nasilju među djecom pri čemu je utvrđeno da 27 \% djece svakodnevno ili gotovo svakodnevno doživljava neke oblike nasilja u školi (verbalnog i tjelesnog) te da se $16 \%$ djece gotovo svakodnevno ponaša nasilno prema drugoj djeci (8 \% djece istovremeno i čini i doživljava nasilje). S obzirom na to da je nasilje prisutno u društvu, a osobito među djecom i mladima, autorice su htjele istražiti koliko nasilja djeca mogu vidjeti u serijama koje su im tematski namijenjene. Druga hipoteza ( $u$ analiziranim serijama najprisutnije je nasilje među djecom s obzirom na to da se radi o dječjoj seriji), opovrgnuta je činjenicom da se u serijama u 25 \% slučajeva radi o upravo takvoj vrsti nasilja, dok je najveći postotak (52,6 \%) slučajeva u kojima možemo vidjeti neki drugi oblik nasilja koji ne uključuje djecu (nasilje među odraslima, nasilje nad životinjama, nasilje među životinjama). U 21,1\% analiziranih scena radi se o nasilju odraslih nad djecom, a u 1,32 \% možemo primijetiti nasilje djece nad odraslima.

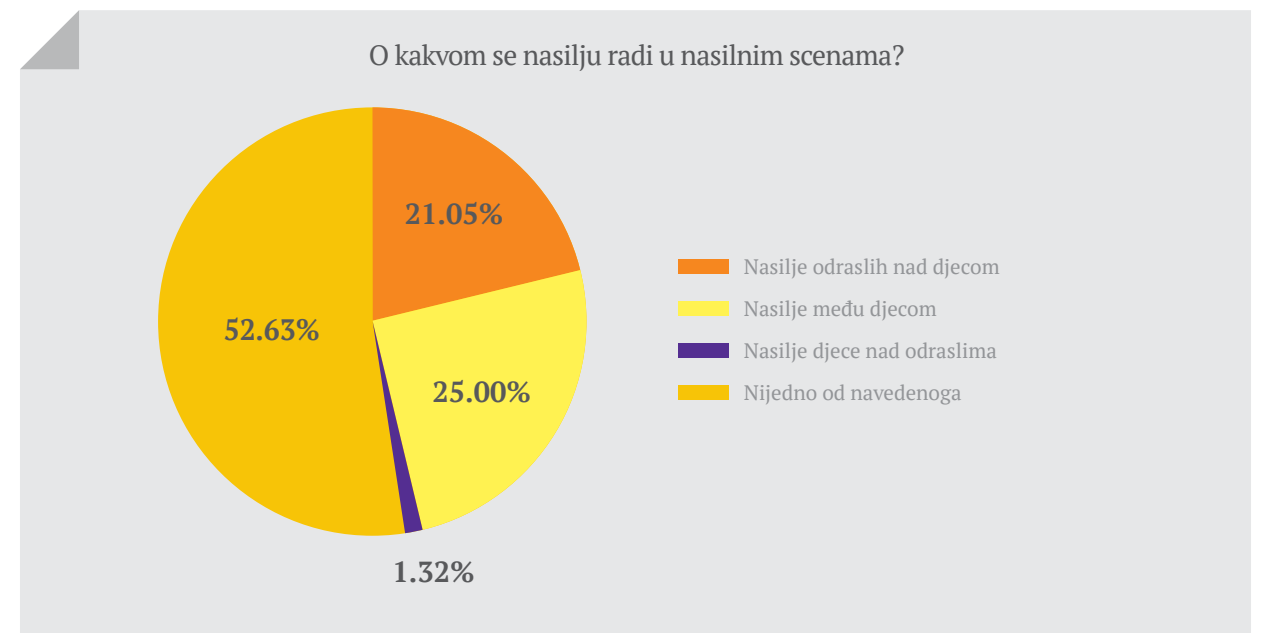

Grafikon 2. Djeca kao sudionici nasilja (N = 77)

Iako u serijama prevladavaju oblici nasilja koji ne uključuju djecu i dalje je vrlo visok udio, 
gotovo četvrtina, scena $u$ kojima možemo vidjeti nasilje među djecom te $u$ vrlo sličnom omjeru je prikazano i nasilje odraslih nad djecom. Scene koje se odnose na nasilje odraslih nad djecom bile su najčešće prikaz kažnjavanja dječjeg neposluha.

$H_{3}: \mathrm{U}$ nasilnim scenama u dječjim serijama Jelenko i Smogovci najzastupljenije je fizičko nasilje.

Kada govorimo o vrsti nasilja prikazanog $\mathrm{u}$ analiziranim scenama, istraživanje je pokazalo da je najzastupljenije ono fizičko koje se pojavljuje u 63,6 \% scena koje sadrže nasilje, slijedi ga psihičko nasilje koje je prisutno u 51,9 \% scena te verbalno u 44,2 \% scena. Važno je napomenuti kako neke scene sadrže više oblika nasilja - kod verbalnog i fizičkog nasilja često je bilo prisutno i psihičko nasilje.

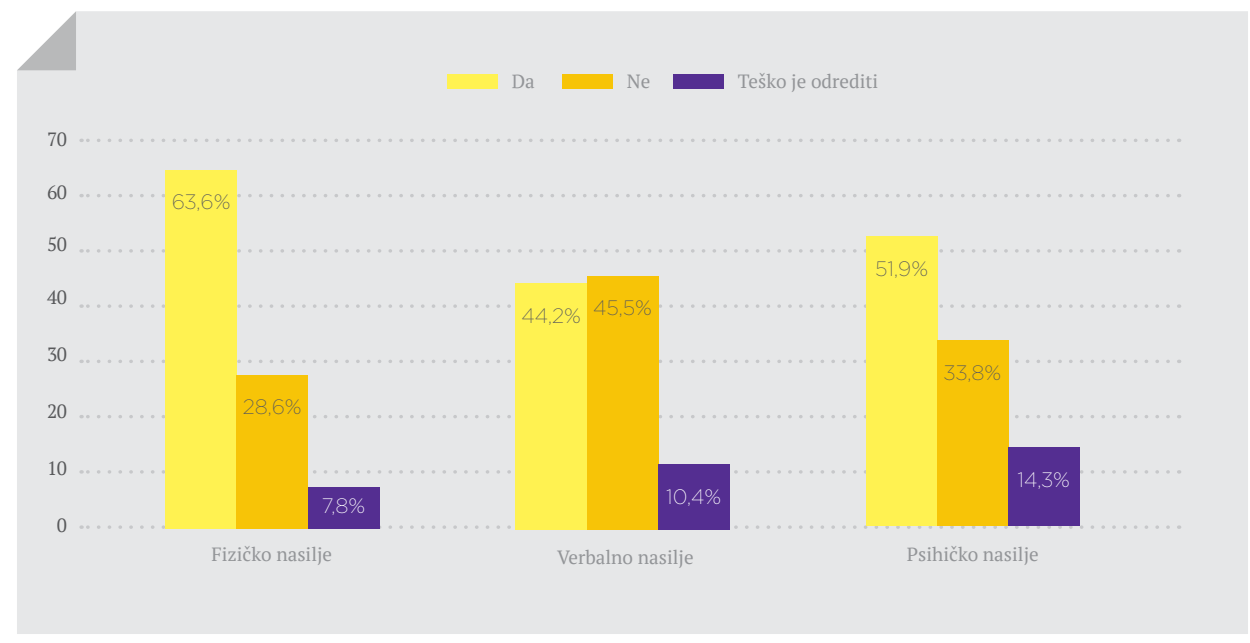

Grafikon 3. Vrste nasilja u scenama koje sadrže nasilje $(\mathrm{N}=77)$

\subsection{Rasprava}

Kao što možemo vidjeti iz rezultata istraživanja, nasilje nad djecom nije bilo rijetka pojava $\mathrm{u}$ analiziranim serijama. Točnije, u seriji Jelenko u $24 \%$ analiziranih nasilnih scena radi se o nasilju odraslih nad djecom. Ovaj postotak upućuje na činjenicu da se u doba radnje serije, dakle početkom 80 -ih godina 20 . stoljeća, fizičko nasilje promoviralo kroz seriju kao odgojna metoda, i to u velikoj količini. Upravo ove scene koje se odnose na nasilje odraslih nad djecom bile su najčešće prikaz kažnjavanja dječjeg neposluha. Jedan od citata 
iz serije koji dobro predočava situaciju $u$ to doba jest: „Batina je iz raja izašla. I mene je otac tuka svaki dan, pa šta mi sad fali“. Također, nakon što djeca jednog dana zakasne kući, „spremaju im šibe i kajiše“ $i$ to se prikazuje kao očekivana posljedica njihovog nemara, tj. dječje zaigranosti i znatiželje - što je zapravo bio razlog njihova kasnijeg dolaska kući. Uz to, iz dječje interakcije i međusobne komunikacije, možemo vidjeti kako je upravo nasilje odraslih nad djecom rezultiralo time da i djeca slijede navedeni obrazac ponašanja. U $28 \%$ analiziranih scena nasilja radi se o nasilju među djecom. Jedna od izjava dječaka Ive je: „Naučit ću ja tebe pameti. I tebe i njega. Još ćemo se mi sresti, platit ćeš ti meni za ovo. Ne šuljajte se po šumi jer će biti batina." Ovakav način govora i prijetnji ne bismo inače očekivali od djeteta, no ovdje je očit prikaz kako djeca kopiraju što vide od roditelja, a mali Ivo je često imao priliku čuti takve fraze od svog oca.

Osim nasilja koje se vidi ili čuje u Smogovcima, u nekim epizodama možemo saznati i o drugim vrstama nasilja koje nisu izravno prikazane u seriji. Tako iz dijaloga Nosonje i inspektora Travice doznajemo da se u obitelji Travica pojavljuje nasilje roditelja nad djecom i između roditelja. Nosonja govori gosp. Travici: „Što?? Istukli ste je?? A no, krasno, krasno. Krasan odgoj. A da niste možda izlemali i mog sina kad i njega nema?" (Smogovci, 1992). Marina Travica u ljubavnom adolescentskom odnosu s Dadom, Nosonjinim sinom, primjenjuje ponašanje članova svoje obitelji, pa tako ošamari Dadu ili mu uputi verbalne uvrede. Takav obiteljski odnos utječe na Marinu koja bježi od doma. U seriji najmlađa članica obitelji Vragec, Lana, često gleda crtane filmove pa ih komentira: „Ubij ga!, Zakolji ga! Tresni ga! Ubij ga još jedanput“. Takve Lanine upute izazivaju čuđenje kod njezine bake Melite koja s Laninom majkom Sonjom razgovara i pita se: „Sonja, ne misliš ti da su ovi crtići malo preagresivni? (...) Mjesto da se širi plemenitost, nenasilje prema ljudima, prema životinjama“ (Smogovci, 1992). Tako su Smogovci postali medij koji je drugom mediju (crtanome filmu) „održao lekciju“ te ukazao na utjecaj nasilja na djecu u crtanim filmovima (Malek, 2016).

Iako Novak (2006) i Paić (2017) opisuju Smogovce kao humorističnu seriju, nasilje (psihičko, verbalno i fizičko) prisutno je u gotovo svakoj analiziranoj epizodi, a kontekst prikaza najčešće nije humorističan. Budući da nema istraživanja o nasilju u hrvatskim dječjim serijama, poslužit ćemo se opisima nasilja u humorističnom kontekstu u animiranim filmovima. U Preporukama za zaštitu djece i sigurno korištenje elektroničkih medija (Agencija za elektroničke medije, 2016) stoji: 
„Nasilje u animiranim filmovima koje nije prikazano u humorističnom kontekstu doživljava se kao nasilje kako kod djece tako i kod odraslih. Neka istraživanja pokazuju kako nakon gledanja humorističnih crtanih filmova više raste vjerojatnost da će djeca biti agresivna prema stvarima nego prema ljudima. Djeca se vrlo često identificiraju s likovima iz animiranih filmova te u samostalnoj igri, ali i u igri s vršnjacima, oponašaju njihov sadržaj (govor likova te njihove pokrete i geste), što je zabrinjavajuće kada je riječ o oponašanju nasilnih sadržaja. Budući da pozitivni junaci često koriste nasilne metode na putu do pobjede, djeci se šalje poruka da je nasilje prihvatljivo. Pojedini animirani filmovi nude opasne ideje koje djeca ponekad, nesvjesna opasnosti, odluče oponašati. Ta činjenica osobito zabrinjava ukoliko se $u$ obzir uzmu rezultati brojnih istraživanja koja su pokazala da je više nasilja u animiranim filmovima, nego u drugim televizijskim sadržajima koji su namijenjeni odraslima.“

Odnos Crnog Đeka i Kumpića, koji su u Naselku poznati po krađama i lopovlucima, prožet je verbalnim uvredama koje najčešće upućuje Crni Đek Kumpiću jer je Crni Džek „predvodnik“ dvojca. Neke od češćih uvreda su idiote, debilu, kretenu i slično. Svakako bi bilo korisno obraditi jezik $u$ Jelenku i Smogovcima te uočiti koje su najčešće uvrede, koliko su zastupljene te tko ih kome i u kakvom kontekstu upućuje. Kao i udarci, i riječi mogu imati veliki utjecaj na primatelja tih uvreda, čak i ako su izrečene $u$ humorističnim situacijama i na humorističan način. U tablici su zato predočene neke verbalne uvrede i prijetnje koje se pojavljuju u analiziranim epizodama obiju serija.

Tablica 1. Verbalne uvrede i prijetnje u Jelenku i Smogovcima

\section{SERIJA JELENKO}

Ivo: „Kad te ja počnem bit, bit ćeš modar ko šljiva.“

Ivin tata: „Magarčino jedna. (...) Sunce vam balavo. Naučit ću ja tebe pameti, upamtit ćeš ti meni pušku magarčino jedna.“

Lovokradica: „Opalit ću ja tebe u glavu. Ne pravi se veća budala nego što jesi. Zazvonit će tebi olovo u glavi.“

Lovokradica: „Umjesto psa, platit ćeš ti. Ubit ću te.“

\section{SERIJA SMOGOVCI}

Papirus: „Tu ste se došli žvaliti, je li? Fakini prokleti! Ako vas još jednom ovdje uhvatim, tako ću vam kosti naravnati da vam više neće pasti napamet cmakanje!“

Dragec Vragec: „Jooj, onda ću te istući prije nego što postaneš nevidljiv.“

Rezultati istraživanja su također pokazali da u seriji Smogovci gledatelji nailaze na dvostruko više nasilnih scena $(\mathrm{N}=52)$, nego u seriji Jelenko $(\mathrm{N}=25)$. Tu činjenicu možemo tumačiti kroz razlike u radnji, razdoblju snimanja serije i samome mjestu radnje. Naime, radnja serije Smogovci prati zagrebačku obitelj i njihove (ne)zgode, a snimana je kroz duži period te obuhvaća različita razdoblja, među njima i Domovinski rat, pa možemo zaključiti da je i tu 
povećan opseg prikazanih nasilnih scena. No, za konkretniju potvrdu navedenog trebalo bi biti provedeno detaljno istraživanje na epizodama koje prate ratno razdoblje. Jedan od razloga popularnosti Smogovaca je i, prema Dudi (2014), prikazivanje obične svakodnevice. Može se zato zaključiti da ono što se događa u životima publike, Smogovci prikazuju na ekranu pa je stoga i veća vjerojatnost povezanosti između stvarnoga i ekraniziranoga svijeta, čak i u aspektu nasilja. Baš zato što prikazuje život u mnogočemu sličan stvarnome životu gledatelja, postoji mogućnost poistovjećivanja gledatelja sa serijom. Što se tiče serije Jelenko, iako je mjesto radnje izmišljeno, a nigdje se službeno ne navodi mjesto snimanja, iz više pokazatelja ${ }^{3}$ možemo zaključiti da je serija snimana u Gorskom kotaru, a radnja prati skupinu djece odraslu u ruralnom području. Već samim time se vidi velika razlika u serijama. U seriji Jelenko djeca poprimaju u govoru i načinu ponašanja odraslih, pa i njihova nasilna djela, pogotovo verbalna - o kojima je već bilo riječi.

Treba napomenuti da Agencija za elektroničke medije (2016) te Ciboci i Osmančević (2014, str. 8) upozoravaju na to da svaki program koji uključuje prizore grubog nasilja mora biti adekvatno označen dobnim oznakama u gornjem desnom kutu ekrana. Kao što je istraživanje pokazalo, u većini analiziranih epizoda ustanovila se barem jedna nasilna scena. Budući da autorice seriju Smogovci nisu gledale kada ju je posljednji put HRT reprizirao, ne mogu tvrditi je li HRT prije emitiranje epizode s nasilnim scenama imao upozorenje o tome da program koji slijedi nije primjeren djeci i maloljetnicima, dok za seriju Jelenko nije korišteno navedeno upozorenje.

\section{Zalključalk}

Analizom dvaju popularnih hrvatskih serijala za djecu i mlade uočena je velika prisutnost nasilnog sadržaja u njima. Rezultati istraživanja pokazuju da je nasilje izravno ili neizravno prikazano u objema serijama. Gledatelji su u gotovo svakoj epizodi suočeni s najmanje jednom nasilnom scenom. Najčešće je prikazano nasilje među odraslima, zatim među djecom ili su djeca žrtve nasilja. Iako postoji i velik broj scena verbalnog i psihičkog nasilja, u serijama prevladava fizičko nasilje.

Jelenko i Smogovci „preslikali“ su stvarni život onoga vremena u kojem su nastali. Budući da se radi o kasnijim godinama druge polovice 20. stoljeća, nasilje nije neuobičajeno. Može li

3 Krajolik, govor i naglasak, mjesto stanovanja djece glumaca. 
se govoriti u kolikoj mjeri se nasilje pojavljivalo nekada i danas, ostaje pitanje, no činjenica jest da se o nasilju općenito više govori danas nego prije. Stoga bi o takvim scenama trebalo razgovarati i kritički im pristupiti kako bi se što bolje shvatio razlog njihove pojavnosti. Analizirane serije spadaju u najpopularnije hrvatske dječje serije koje se svakih nekoliko godina iznova repriziraju. Može se pretpostaviti da baš zbog tih simpatija koje gledatelji gaje prema serijama, vjerojatno ni sama publika nije svjesna toga da su nasilne scene toliko učestale. Kako bi se izbjegli mogući negativni utjecaji, potrebno je pratiti što djeca gledaju te razgovarati s njima o pogledanim sadržajima, objasniti im ono što je možda nejasno te ih svakako upozoriti da ne pokušavaju kopirati viđeno nasilje. Jedino kvalitetnim dijalogom u obitelji te uz pomoć formalnog i neformalnog medijskog odgoja možemo pokušati umanjiti potencijalne negativne utjecaje televizijskog nasilja na djecu.

Potreba za medijskim obrazovanjem, iako se danas nalazi na vrhuncu, postoji već dugi niz godina. Medijski odgoj nas uči kako kritički i razborito promišljati o medijima i porukama koje nam šalju. U Hrvatskoj djeca i mladi kroz obrazovni sustav imaju formalnu mogućnost tek djelomično se obrazovati o medijima (prvenstveno o filmu, a onda ponešto i o televiziji i radiju), vrlo malo o medijskoj produkciji (kroz rad u školskim novinama, školskom radiju te kroz filmske radionice), a najmanje o analizi i kritičkom vrednovanju medijskih sadržaja, što je zapravo temelj medijske pismenosti (Kanižaj, Car, 2015, str. 29). Ovako postavljena medijska pismenost prilično se razlikuje od suvremenog koncepta medijskog odgoja, koji je ipak nešto širi u teorijskom i praktičnom smislu. To je koncept koji pokušava omogućiti djeci, roditeljima i nastavnicima da odgovore na agresivnu ulogu koju mediji imaju danas u životu djece i obitelji iako škola u Hrvatskoj s ovako koncipiranim medijskim odgojem još nije spremna odgovoriti snazi medija (Erjavec, Zgrabljić Rotar, 2000, str. 95).

Brojni su pozitivni primjeri škola koje su samoinicijativno, zahvaljujući entuzijazmu odgojno-obrazovnih djelatnika, osnovale vlastite sekcije medijske kulture, novinarstva, filmske umjetnosti i slično. Tamo djeca mogu na praktičan i zanimljiv način naučiti mnogo o medijima, produkciji medijskih sadržaja, a i sami se okušati u stvaranju istih. U sklopu navedenih sekcija s učenicima se može razgovarati o nasilju u sadržajima namijenjenima djeci, objasniti im moguće negativne utjecaje te ih poticati da odabiru kvalitetne sadržaje, primjerene njihovoj dobi. Također, možemo predložiti djeci da i sama pokušaju uočiti i bilježiti nasilne scene u dječjim serijama kako bi i sama osvijestila prisutnost takvih scena.

4 http://os-dalj.skole.hr/skola/skolske_novine, http://www.gimnazija-pula.skole.hr/nastava/fakultativna_nastava/medijska_kultura, http://www.gimnazija-sesvete.skole.hr/novinarska_skupina 
Važnu ulogu u medijskom opismenjavaju u Hrvatskoj ima izvaninstitucionalni odgoj. Zahvaljujući naporima koje razne organizacije civilnog društva i institucije ulažu u edukaciju djece, roditelja i odgojno-obrazovnih djelatnika, medijski odgoj se polako počinje širiti, a dionici shvaćati ulogu i potrebu za edukacijom o medijima. S obzirom na to da i sami učitelji hrvatskog jezika ističu da im je potrebna dodatna edukacija i usavršavanje o medijima i medijskoj kulturi (Ciboci, Osmančević, 2015, str. 130), kao korisne stranice za pronalazak literature i primjera za rad s učenicima ističemo portale www.medijskapismenost.hr Agencije za elektroničke medije i www.djecamedija.org Društva za komunikacijsku i medijsku kulturu.

Ovim radom dali smo teorijski uvod u nasilje na televiziji i njegove utjecaje te provedbom istraživanja pokazali da se u popularnim hrvatskim dječjim serijama Smogovci i Jelenko nalazi velika količina nasilnih scena. Također, dali smo osnovne preporuke za razgovor i rad s djecom u obitelji i školi kako bi se izbjegao i umanjio mogući utjecaj nasilnih televizijskih sadržaja na djecu. S obzirom na to da je ovo istraživanje manjeg obujma, potrebna su daljnja istraživanja postojećih serija kako bi se moglo provesti sveobuhvatno istraživanje na većem uzorku i na taj način dati jedan cjelovit pregled nasilja u hrvatskim dječjim serijama.

\section{Popis literature}

- Agencija za elektroničke medije (2016). Preporuke za zaštitu djece i sigurno korištenje elektroničkih medija. Dostupno na: https://www.medijskapismenost.hr/wp-content/uploads/2016/09/medijska-pismenost-preporuke-dokument.pdf. Preuzeto 29. siječnja 2019.

- Bilić, V. (2010). Povezanosti medijskog nasilja s agresivnim ponašanjem prema vršnjacima. Odgojne znanosti, 12, 2 (20), $263-281$.

- Bandura, A. (1994) Social cognitive theory of mass communication, 61-90. U: Bryant, J., Zillmann, D. (ur.), Media Effects: Advances in Theory and Research. Hillsdale, NJ: Lawrence Erlbaum.

- Blanuša Trošelj, D., Srića, S. (2014). Tv-sadržaji i slobodna igra djece u vrtiću. Croatian Journal of Education, 16 (1), $25-41$.

- Blažević, N. (2012). Djeca i mediji - odgoj na ‘televizijski’ način. Nova prisutnost, 10 (3), 479-493.

- Ciboci, L,. Osmančević L. (2015). Kompetentnost nastavnika hrvatskog jezika za provođenje medijske kulture u hrvatskim osnovnim školama, 121-139. U: Car, V., Turčilo, L., Matović, M. (ur.), Medijska pismenost - preduvjet za odgovorne medije. Sarajevo: Fakultet političkih nauka Univerziteta u Sarajevu.

- Duda, I. (2014). S Bucom i Bongom protiv krize. Hitrecovi smogovci, djetinjstvo i svakodnevica kasnog socijalizma. Historijski zbornik, 67 (2), 401-418.

- Erjavec, K., Zgrabljić Rotar, N. (2000). Odgoj za medije u školama u svijetu Hrvatski model medijskog odgoja. Medijska istraživanja, 1 (6), 89-107.

- Gunter, B., Harrison, J., Wykies, M. (2003) Violence on Television. Distribution, Form, Context and Themes. Mahwah, New Yersey: Lawrence Erlbaum Associates, Inc., Publishers.

- Ilišin, V. (2001). Konceptualni okvir istraživanja, 9-42. U: Ilišin, V., Marinović Bobinac, A., Radin, F. (ur.), Djeca i mediji. Zagreb: Državni zavod za zaštitu obitelji, materinstva i mladeži Institut za društvena istraživanja u Zagrebu. 
- Ilišin, V. (2003). Mediji u slobodnom vremenu djece i komunikacija o medijskim sadržajima. Medijska istraživanja, 9 (2), 9-34.

- Ilišin, V. (2017). Neke dimenzije slobodnog vremena mladih, 293-316. U: Ilišin, V., Spajić Vrkaš, V. (ur.), Generacija osujećenih. Mladi u Hrvatskoj na početku 21. stoljeća. Zagreb: Institut za društvena istraživanja u Zagrebu.

- Kanižaj, I., Car, V. (2015). Hrvatska: Nove prilike za sustavan pristup medijskoj pismenosti, 19-38. U: Car, V., Turčilo, L., Matović, M. (ur.), Medijska pismenost - preduvjet za dogovorne medije. Sarajevo: Fakultet političkih nauka Univerziteta u Sarajevu.

- Kanižaj, I., Ciboci, L. (2011). Kako je nasilje preko medija ušlo u naše domove, 11-34. U: Ciboci, L., Kanižaj, I., Labaš, D. (ur.), Djeca medija. Od marginalizacije do senzacije. Zagreb: Matica hrvatska.

- Kirsh, S. J. (2006). Children, adolescents and media violence: a critical look at the research. Thousand Oaks, London, New Delhi: SAGE Publications.

- Kunczik, M., Zipfel, A. (1998). Uvod u publicističku znanost i komunikologiju. Zagreb: Zaklada Friedrich Ebert.

- Kunczik, M., Zipfel, A. (2007). Mediji i nasilje: aktualno stanje u znanosti. MediAnali, 1 (1), 1-26.

- Malek, L. (2016). Smogovci u ratu protiv medijskog nasilja. Global, 3 (14), 12.

- Mikić, K. (2001). Film u nastavi medijske kulture. Zagreb: Educa.

- Mlinarević, V. (2004). Dijete i televizija, 39-46. U: Babić, N., Irović, S., Redžep-Borak, Z. (ur.), 3. stručni i znanstveni skup Rastimo zajedno: zbornik radova. Osijek: Centar za predškolski odgoj; Visoka učiteljska škol: Grafika.

- Novak, B. (ur.) (2006). Leksikon radija i televizije. Zagreb: Masmedia.

- Potter, W. J. (1999). On media violence. Thousand Oaks, London, New Delhi: SAGE Publications.

- Šego, J. (2009). Obrazovanje za medije - doprinos medijskoj kompetentnosti i kulturi odgovornosti, 61-76. U: Labaš, D. (ur.) Novi mediji - nove tehnologije - novi moral. Zbornik radova Okrugloga stola s međunarodnim sudjelovanjem. Zagreb: Hrvatski studiji Sveučilišta u Zagrebu.

- Trend, D. (2007). The Myth of Media Violence. A Critical Introduction. Malden: Blackwell Publishing.

- Valković, J. (2010). Oblici i utjecaj televizijskog nasilja. Nova prisutnost, 8 (1), 67-86.

- Zgrabljić Rotar, N. (ur.) (2005). Medijska pismenost i civilno društvo. Sarajevo, Media Centar.

- Wright, J. C., Huston, A. C., Reitz A. L., Pieymat S. (1994). Young children's perceptions of television reality: determinants and developmental differences. Dev Psychol, 30 (2), 229-239.

\section{Internetski izvori}

- Američka pedijatrijska akademija (2009). Media Violence. Pediatrics, 124 (5). Dostupno na:

- http://pediatrics.aappublications.org/content/124/5/1495..info. Preuzeto 10. siječnja 2018.

- Ciboci, L., Osmančević, L. (2014). Mediji bez nasilja? Edukativna brošura. Zagreb: Društvo za komunikacijsku i medijsku kulturu. Dostupno na:

- Enciklopedija.com (n.p.). Scena. Dostupno na: http://www.enciklopedija.hr/Natuknica.aspx?ID=54808. Preuzeto 29. siječnja 2019.

- Ofcom (2017). Children and Parents: Media Use and Attitudes Report. Dostupno na:

- https://www.ofcom.org.uk/_data/assets/pdf_file/0020/108182/children-parents-media-use-attitudes-2017.pdf, Preuzeto 31. siječnja 2019.

- Paić, V. (2017). Gdje su Smogovci danas. HRT Magazin - Hrvatska radiotelevizija. Dostupno na: http://magazin.hrt.hr/388692/ gdje-su-smogovci-danas. Preuzeto 19. studenoga 2017.

- http://dkmk.hr/wp-content/uploads/2016/01/medijibeznasilja.pdf. Preuzeto 29. siječnja 2019.

- Poliklinika za zaštitu djece grada Zagreba (2003). Nasilje među djecom. Dostupno na: https://www.poliklinika-djeca.hr/ istrazivanja/nasilje-medu-djecom-3/. Preuzeto 10. prosinca 2017.

- Poliklinika za zaštitu djece i mladih Grada Zagreba (2017). Prvo nacionalno istraživanje o predškolskoj djeci pred malim ekranima (rezultati). Dostupno na https://www.poliklinika-djeca.hr/istrazivanja/prvo-nacionalno-istrazivanje-opredskolskoj-djeci-pred-malim-ekranima/. Preuzeto 31. siječnja 2019. 


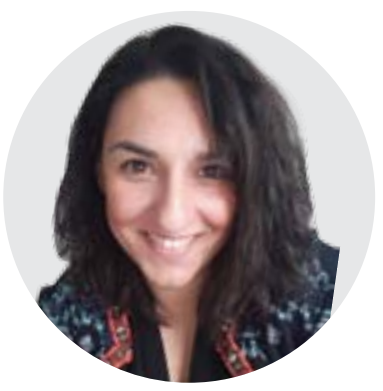

Lina Malek

Lina Malek rođena je 1992. $\mathrm{u}$ Zagrebu. $\mathrm{Na}$ Hrvatskim studijima Sveučilišta u Zagrebu diplomirala je komunikologiju i kroatologiju. Sudjelovala je u Erasmus studentskoj razmjeni pri Institutu za slavistiku Sveučilišta u Heidelbergu, $\mathrm{u}$ Njemačkoj. U ljetnom semestru ak. god. 2017./2018. bila je vanjska suradnica na kolegiju „Akademska pismenost" na Hrvatskim studijima. Od prosinca 2018. doktorandica je na poslijediplomskom studiju kroatologije. Dobitnica je Rektorove nagrade za društveno koristan rad u akademskoj i široj zajednici, Stipendije za izvrsnost Sveučilišta u Zagrebu i Priznanja voditelja Hrvatskih studija. Sudjelovala je kao izlagačica na dvama znanstvenim kolokvijima u organizaciji Društva studenata kroatologije Cassius. Aktivna je članica Društva za komunikacijsku i medijsku kulturu i Udruge Ekomuzej Bistra.

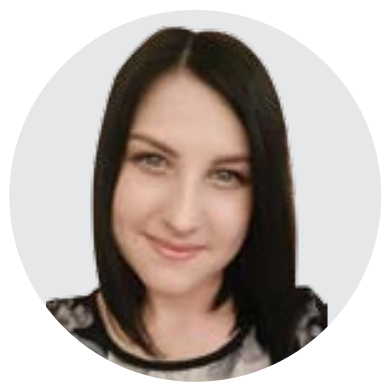

\section{Tina Regg}

Tina Regg magistrirala je komunikologiju na Hrvatskim studijima Sveučilišta u Zagrebu - smjer odnosi s javnošću. Na diplomskom je studiju, putem razmjene studenata, studirala na sveučilištu Vilniaus universitetas u Litvi, na odjelima Faculty of Communication, Journalism and Information i Journalism and Reporting, te sveučilištu National Sun Yat-sen University u Tajvanu, na odjelima Institute of Marketing Communication, Institute of Human Resource Management i Master of Business Administration Program in International Business. Od 2013. godine je predavačica u Društvu za komunikacijsku i medijsku kulturu, a u sklopu projekta Mind Over Media, kreirala je prvi kurikul o propagandi namijenjen edukaciji migranata i tražitelja azila.

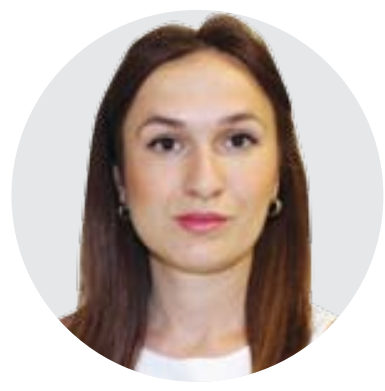

\section{Katarina Blažina Mukavec}

Katarina Blažina Mukavec rođena je u Zagrebu. Magistrirala je komunikologiju, smjer odnosi s javnošću, na Hrvatskim studijima Sveučilišta u Zagrebu 2015. godine. Od 2012. godine aktivna je članica Društva za komunikacijsku i medijsku kulturu, a od 2016. godine koordinatorica sekcije predavača u projektu Djeca medija kojeg Društvo provodi s ciljem poboljšanja medijske pismenosti građana Republike Hrvatske. Koordinirala je i druge projekte medijske pismenosti koji su se provodili uz potporu ministarstava, jedinica lokalne uprave i drugih organizacija civilnoga društva. Koautorica je brošure Mediji (i) naši učitelji. Znanstveni interesi su joj medijska pismenost, zaštita privatnosti i sigurnosti djece na internetu, nasilje $u$ medijima $i$ općenito odnos djece i medija. 